\title{
Examining the cohesiveness and nestedness entrepreneurial ecosystems: evidence from British FinTechs
}

\author{
Ben Spigel
}

Accepted: 24 November 2021 / Published online: 2 January 2022

(C) The Author(s) 2021

\begin{abstract}
It is not clear if entrepreneurial ecosystems are cohesive wholes within a region that support high-growth entrepreneurship across a variety of sectors or if ecosystems are made up of several, nested sectoral-specific sub-ecosystems. This debate speaks to larger disagreements about what entrepreneurial ecosystems are and how they work. This paper addresses this research gap by using a novel methodology based on career history data of founders and top management teams of high-growth FinTech ventures. This method is used to classify the backgrounds of 1,570 individuals in 380 British FinTech firms based on their prior job histories and employers into categories such as technology or finance. The paper finds substantial evidence of nestedness in the ecosystems, but rather than FinTech ecosystems being specialized finance or technology clusters, more generic forms of managerial know-how remain crucial to firm innovation and growth. This suggests that even very advanced ecosystems remain nested, with few cross-over points between different communities.
\end{abstract}

Plain English Summary Are entrepreneurial ecosystems made up of one cohesive community of all high-growth entrepreneurs in a region or are they made up of several nested sub-ecosystems organized

B. Spigel $(\bowtie)$

University of Edinburgh Business School, Edinburgh, UK

e-mail: ben.spigel@ed.ac.uk around a particular sector? This seems like a minor conceptual matter, but it speaks to the heart of what entrepreneurial ecosystems are and why they matter for economic development policy. I use a new approach to examine the backgrounds of FinTech entrepreneurs in four British ecosystems to better understand the extent to which FinTech firms emerge out of founding teams with backgrounds in finance and technology. I find that there is very little overlap between these communities and that the regions have nested ecosystems. However, the data show the importance of founders and top managers with generalist managerial backgrounds which suggests that more generic forms of business knowledge are very important in the scale-up process.

Keywords Entrepreneurial ecosystems · FinTech · Opportunities · Geography

JEL Classifications $\quad$ L26 $\cdot$ M12 $\cdot$ M13

\section{Introduction}

Building strong entrepreneurial ecosystems - the localized actors and factors that support highgrowth entrepreneurship — has emerged as a popular regional economic development strategy (Spigel, 2020; Wurth et al., 2021). While researchers have discussed different definitions of ecosystems (e.g., Audretsch \& Belitski, 2016; Cao \& Shi, 2020), 
these works all stress the importance of common factors such as active investment scenes; leadership from entrepreneurs; dense networks connecting founders, advisors, mentors, and employees; knowledge spillovers from universities and major corporations; and a culture that supports innovation and risk-taking. These place-based factors provide the economic and social support needed to encourage ambitious, growth-oriented entrepreneurship. But given the rapid growth of the entrepreneurial ecosystem literature, there are numerous research gaps. One of the most important unanswered questions is if regions have a single, cohesive ecosystem through which entrepreneurial resources and support circulate or if regions contain several "nested" ecosystems centered around individual industries. While scholars such as Brown and Mason (2017) and Auerswald and Dani (2017) have suggested that ecosystems have multiple nested communities, others suggest that ecosystems are cohesive, with sharing of knowledge and resources between firms in different sectors (Mack \& Mayer, 2016; Motoyama \& Knowlton, 2016).

Determining if ecosystems are cohesive or nested is more than a conceptual quibble: it speaks to the heart what entrepreneurial ecosystems are, how they operate, and how they contribute to firm competitiveness. Recent developments in technologies such as digital platforms (Ewens et al., 2018) and the spread of entrepreneurial methodologies like Lean Startup (Contigiani \& Levinthal, 2019) have arguably made the skills required for scaling up entrepreneurial ventures more generic. This means that entrepreneurs in different sectors benefit from similar knowledge bases, such as how to pitch to investors or use advertising platforms. If these generic types of entrepreneurial know-how are the most essential part of the scale-up process, we would expect regions to have a single, cohesive entrepreneurial ecosystem. On the other hand, if industryspecific knowledge and know-how are more important to scaling, we would expect to see regions to develop nested ecosystems where entrepreneurs in similar sectors benefit from interacting with one another rather than outsiders.

The FinTech sector is a useful case to study the role of generic and specific knowledge and resources in ecosystems. FinTech firms use digital technologies to solve problems and reduce costs in the financial services sector. Successful FinTech entrepreneurship requires insight into both the finance industry in order to identify and evaluate potential opportunities and technological knowledge to develop new products and services that provide value and lower costs (Harris, 2021). In theory, FinTech firms should benefit from an integrated ecosystem that allows technical and business knowledge to flow between the finance and technology sectors. However, the financial industry is notoriously opaque, which makes it difficult for outsiders to draw on the insights of those in the industry to find and exploit emergent entrepreneurial opportunities. It is difficult to say if growth in the FinTech space is driven by the concentration of specialized knowledge that allows entrepreneurs to find and exploit emergent opportunities or if it is driven by more generic forms of entrepreneurial knowledge around how to develop and scale products.

The extent to which FinTech ecosystems are cohesive or nested speaks to the underlying processes through which ecosystems develop and support the competitive advantage of high-growth ventures. Individual choices by ecosystem actors such as who they meet and choose to partner with are made within the broader context of ecosystem norms and networks, which structure the potential options available to individuals at any given time. The configurations of ecosystems provide a way to understand the often-invisible mechanism which connect ecosystem structure with entrepreneurial action. This does not mean that ecosystems are deterministic nor that regions cannot have multiple configurations. Rather, examining the extent to which entrepreneurial ecosystems have a cohesive or nested structure allows us to better understand the underlying pressures affecting how ecosystems work.

To investigate this tension, this paper examines the backgrounds of the founding and management teams of British FinTech scale-ups. The paper uses a novel analytical methodology to classify the backgrounds of the founders, senior managers, and advisors of high-growth FinTech firms in the City of London, East London, Leeds, and Edinburgh. These regions have the highest concentration of FinTech firms in the United Kingdom. In total, data was gathered on 1,570 founders, top managers, and advisors at 380 highgrowth FinTech firms. The nature of founding and 
management teams are examined because the skills, knowledge bases, and networks of these individuals are a crucial determinant of firm success (Barringer et al., 2005; Hasan \& Koning, 2019). In particular, the paper examines these actors' knowledge base: if they have work experience in the finance industry, digital technology, or other sectors. Their work experience and backgrounds potentially give founders and managers key insights into markets and new technologies that could spark FinTech entrepreneurial innovation. These data are used to understand the extent of overlap between people whose backgrounds are in technology, finance in order to understand the cohesiveness or nestedness of different FinTech ecosystems. This provides a quantitative measure of ecosystem cohesiveness which sheds new light on their structure and level of development.

The data suggest that ecosystems are generally nested, with founding teams generally coming from one type of background (e.g., technology). Where there is overlap, it tends to be between people with either a background in finance or technology with someone from a managerial background. This suggests that FinTech entrepreneurship does not require an overlap of specialized finance and technology knowledge, but rather requires similar, generic forms of scale-up know-how. The ecosystem is useful for connecting founders with similar backgrounds to advisors and top managers with more diverse knowledge bases. These findings make three contributions to the entrepreneurial ecosystems literature. First, it argues that ecosystems remain nested, even in highly developed economies such as in London. This helps resolve long-standing questions about ecosystems structure. Second, it develops a new, repeatable methodology that can measure the cohesiveness of different entrepreneurial ecosystems across nations and over time. This responds to calls for better use of new data sources from digital platforms and social media (Feldman, 2014; Feldman \& Lowe, 2015). Such an approach allows for more robust empirical comparisons within and between ecosystems. Third and most importantly, it explores the importance of generic industry-specific knowledge in entrepreneurial ecosystems and the importance of these different types of knowledge in the modern scale-up entrepreneurship process.

\section{Entrepreneurial ecosystems, knowledge, and structure}

\subsection{Entrepreneurial ecosystems}

Scholars have long understood that there is an uneven geography to entrepreneurship. A large research literature has found that regional attributes such as high levels of human capital (Acs \& Armington, 2004), sustained economic growth (Lee \& Osteryoung, 2004), clustering of firms in similar industries (H. O. Rocha \& Sternberg, 2005), and cultural support for the risks of entrepreneurship (Beugelsdijk \& Noorderhaven, 2004) are correlated with higher levels of entrepreneurship. However, not all entrepreneurship is created equal: a small proportion of all new ventures are responsible for the bulk of all new job creation in regions (Brown \& Mason, 2017). While not all high-growth firms can be considered socially productive in the sense of Baumol (1990) - and indeed, some high-growth firms like predatory payday lenders could be considered destructive - most highgrowth firms create new wealth through finding new ways to create value for customers (Spigel, 2020). This makes supporting this kind of entrepreneurship a crucial element of regional economic development strategies in order to build stable, resilient economies (Brown \& Mawson, 2019).

Though the term "entrepreneurial ecosystem" has been used by many different scholars, its modern usage has solidified around a focus on the relationships between a series of individual and organizational actors and economic and social factors within a region that support the emergence and growth of scale-up entrepreneurship (Neumeyer \& Corbett, 2017; Stam, 2015). Ecosystems differ from other territorial-based theories of economic development such as clusters and innovation systems due to their focus on the types of regional environment that impact high-growth entrepreneurs and the importance of entrepreneurs' own agency in creating this supportive environment rather than the public sector or large corporations. Recent papers have identified common attributes of successful entrepreneurial ecosystems ecosystem including actors such as investors, advisors, mentors, skilled workers, research universities, and accelerators, as well as factors such as a culture that supports risk-taking and innovation, 
dense networks within the community, and welldesigned public support for entrepreneurship (Chen et al., 2019). Ecosystems can emerge out of successful institutions such as a research university or organically from the activities of engaged entrepreneurs and dealmakers working to create a better environment for themselves (Cantner et al., 2020). At the heart of the entrepreneurial ecosystems, perspective is the centrality of individual entrepreneur and their power to create their own context. This extends to non-founders who are heavily involved with new ventures, such as senior executives, board members, and advisors. While these actors are embedded in social and economic structures that constrain their choices, they still retail the freedom to develop new ideas and approaches that affect the success of their venture and the future of the ecosystems they operate within.

While the first wave of ecosystems research sought to define the actors and factors that support highgrowth entrepreneurship, this has been critiqued for ignoring the processes by which these actors and factors influence entrepreneurial strategy and performance (Wurth et al., 2021). Spigel and Harrison (2018) suggest a process-oriented perspective of ecosystems that looks at how entrepreneurs engage with their ecosystem to acquire the resources required to start and grow innovative new ventures. These resources extend beyond traditional assets such as financial capital to also include technical knowledge; business know-how relating to firm growth; and access to skilled employees, mentors, and advisors. Ecosystems with dense networks between entrepreneurs and their surrounding business community and dealmakers who invest their own social capital in developing the region's business environment will help ease the flow of resources and know-how throughout the community (Pittz et al., 2019).

\subsection{Knowledge, affordances, and ecosystem structure}

Research on entrepreneurial ecosystems is influenced by prior work on industrial clusters, in which the proximity between firms in the same industry can be a source of competitive advantage (Porter, 1998). One of the major debates within this domain, and which has carried over to ecosystems debates, is if the biggest advantages are found in specialized clusters with many firms in the same industry or in diverse clusters with firms in different industries.
Clusters focused around a single industry can create strong supply-chain relationships between local firms that allow for sharing of highly technical knowledge, driving down cost through process innovation and higher economies of scale (Ketelhöhn, 2006). But in more diverse clusters, knowledge spillovers between nearby firms in different sectors have the potential to spur radical new innovations through the recombination of distinctive knowledge bases. Knowledge flows between industries allow very different firms to benefit from knowledge spillovers that suggest new ways to employ or recombine existing technologies or products to serve new markets. Even in regions with multiple, more specialized clusters, knowledge flows between different firms help to spur more innovation and growth (Bathelt \& Zhao, 2016).

Thinking on the cohesiveness or nestedness of ecosystems is also informed by work on related and unrelated variety. Theories of evolutionary economics see entrepreneurs as being influenced by their previous experiences, leading them to start new ventures related similar to that of their prior employers, but with new approaches that allow them to build new sources of value (Klepper, 2007). This leads to the emergence of specialized clusters or ecosystems based around a core knowledge or industry (Henry et al., 2021). This privileges deep knowledge of a sector that allows for incremental innovation and finding new ways to serve existing groups of customers. However, firms with high levels of absorptive capacity can produce unrelated variety, in which they take on insights and ideas from other sectors to create new innovations and ways to create value (Fritsch $\&$ Kublina, 2018). Such development paths require a broader knowledge base and networks in order to observe activities happening in very different markets and the ability to synthesize new insights into potentially radical new innovations.

The primary models of entrepreneurial ecosystems by Isenberg (2010), Stam (2015), and Spigel (2017) have implicitly viewed ecosystems as unified wholes with few barriers between sectors. Two assumptions about the high-growth entrepreneurship process drove this view. First, many parts scale-up firms' lifecycle are substantially similar regardless of sector. Activities such as identifying and validating potential opportunities, pitching to investors, and managing cash flow and growth are similar across a wide swath of consumer- or business-oriented sectors. Indeed, 
common tools such as the Business Model Canvas or the Lean Startup approach position themselves as generic methodologies that can be applied to a wide range of different business types (Massa et al., 2017). These tools have led to general scale-up entrepreneurship paths that focus on quick engaging with the market through experimentation and then rapid pivoting of the underlying business model based on what is learnt through this process (Contigiani \& Levinthal, 2019). While each firm is on its own journey, there are now more commonalities between the growth experiences of firms than 20 or 30 years ago when there were more differences between sectors.

Second, entrepreneurs and businesses of all sizes are increasingly using similar business and technological platforms to develop, market, and distribute their products and services. This is linked to both new technologies such as cloud computing that reduce the cost of such platforms and more fundamental shifts in business structure brought on by digitalization. The ability to gather, process, and learn from market data is becoming increasingly important no matter if a firm is in manufacturing, consumer goods, or knowledge-intensive business services. Autio et al. (2018) adopt the concept of digital affordances to describe this trend. Indeed, the entire concept of the separation between technology firms and non-technology firms is increasingly questioned as more firms outside the digital sectors are adopting these methodologies and approaches (Nathan \& Rosso, 2015). Recent work on territorial servitization has shown how the knowledge bases of manufacturing and knowledge-intensive business firms can combine to create new business models and sources of competitive advantage (Lafuente et al., 2017). The elements of a well-functioning entrepreneurial ecosystems, such as dense regional networks, create new pathways to combine these knowledge bases, allowing for new ways to create value (Horváth \& Rabetino, 2019).

Both these developments suggest that high-growth entrepreneurs now have common business and technology toolkits that allow them to interact and share knowledge regardless of their home market. Within entrepreneurial ecosystems, it is increasingly the case that founders "read the same books, follow the same thought leaders, and use similar tools and methods" (van Weele et al., 2017, p. 181). This shared knowledge base makes it easier for entrepreneurs to learn from peers in their ecosystem even if they are not in the same sector. Prior to these shifts, entrepreneurs in different sectors had less they could learn from each other. As learning is a key element of startup support and acceleration programs, this means that these programs can draw on a broader array of entrepreneurs without limiting what users can learn from each other (Cohen et al., 2018).

On the other hand, authors such as Brown and Mason (2017) and Stam and van de Ven (2021) argue that we should expect multiple, nested ecosystems within a region based around particular industries or specializations. This argument draws on the specialization view of clusters, in which firms competing and cooperating in similar fields build up shared infrastructure and untraded interdependencies which drive down costs for everyone involved. Firms in similar fields develop more absorptive capacity in their areas of specialization, allowing them to benefit more from knowledge spillovers from both other firms in the same sectors as well as from new research at local universities (Qian et al., 2013). Nested ecosystems for specific sectors also allow for more specialized support services, for example, lawyers who are knowledgeable about IP issues regarding biotech products or investors with a deep knowledge of the satellite industry (Auerswald \& Dani, 2017). The development of such specialized support networks was seen by Kenney and Patton (2005) as a crucial stage in the development of strong ecosystems like Silicon Valley. Similarly, specialized ecosystems allow for the development of a skilled workforce in particular niches, lowering employment and training costs for new firms. This is not to say that nested ecosystems are their own, self-sustaining communities cut off from their broader regional business and entrepreneurial community. Bridges between nested ecosystems in a region will form through work by public sector organizations such as chambers of commerce and startup support organizations as well as through local dealmakers with dense and diverse local networks.

This tension between nested or cohesive entrepreneurial ecosystems is similar to earlier debates about the role of a firm's knowledge base - the breadth of its knowledge across multiple fields or its depth in a particular niche - in its innovative capacity and success (Zhou \& Li, 2012). Radical innovation requires a combination of both types of knowledge. A broad knowledge base allows firms to identify new needs and solutions that are not yet present in 
markets while a deep knowledge base allows a firm to develop advanced new products. In addition to technical knowledge (know-what), this knowledge also includes "know-how" about how to apply knowledge to functional ends and "know-who" which refers to the ability to leverage social networks to support business operations (Asheim \& Gertler, 2006). From this perspective, knowledge is a key firm resource which is directly responsible for a firm's ability to achieve sustained competitive advantage (Felin \& Hesterly, 2007). The particular configuration of knowledge that is most beneficial to a firm depends on their sectoral and geographic environment, with deep domain knowledge being advantageous in R\&D intensive industries and broader knowledge more useful in markets characterized by rapidly changing customer needs (Doloreux \& Turkina, 2021; Maleki \& Rosiello, 2019). The type of knowledge a firm needs to achieve competitive advantage also changes over the course of a firm's lifecycle. Initially, a technology-driven company may need deep technical and scientific knowledge to develop a new cutting-edge product. However, as the company grows, it will need to acquire a broader base of market know-how and industry know-who in order to scale operations, gain financing, and expand its market reach (Schildt et al., 2012).

\subsection{Cohesive and nested FinTech entrepreneurial ecosystems}

The FinTech industry is a useful way to understand the dynamics and structures of entrepreneurial ecosystems. FinTech refers to the use of new digital technologies to provide higher-value solutions in the financial services sector (Philippon, 2016). This ranges from high-speed quantitative trading systems for global banks to small-scale consumer budgeting apps. While the financial industry has always employed new technologies, earlier innovations like ATMs were historically developed by large financial services institutions themselves. But by the 2008 Financial Crisis, the continuing digitization of financial services, reduced costs of software development, and shifting regulatory structures have lowered barriers of entry for new ventures to develop innovative financial products for both enterprise and consumer markets (Arner et al., 2016).
While the means of production of finance products may be democratized, the finance industry itself remains opaque and hard for outsiders to access. It is difficult for those without experience in the industry to observe opportunities in this market and validate solutions. Entrepreneurs without a track record in the finance industry may find it hard to develop legitimacy or networks to sell their product to senior financial executives successfully (Ho, 2009). This means that entrepreneurs with a background in the finance industry are more likely to be able to observe and act on opportunities in this sector. At the same time, FinTech firms obviously need technological expertise. Founders require insights into emerging technologies to understand if these developments create new opportunities to solve what were formally intractable problems. Having this knowledge internal to the founding team may be critical, as outsourcing technology validation and product development is very risky (Nakatsu \& Iacovou, 2009). But technologists without experience in the finance industry will face difficulty in identifying and validating opportunities in the FinTech sector.

A cohesive ecosystem may increase the chances of entrepreneurs with different backgrounds of meeting, sharing ideas, and ultimately agreeing to develop a new venture together. Dense, interconnected networks between different sectors in a cohesive ecosystem will create collisions between nascent entrepreneurs with different skill and knowledge bases (Nylund \& Cohen, 2017). This creates favorable conditions for financial services entrepreneurs to combine their knowledge of unmet needs in the industry with insights into new ways to solve problems by those with a background in digital technology. Additionally, founders and managers from outside these two industries can contribute their own unique perspectives to help drive new innovation. The opportunity to repeatedly encounter each other in informal, social situations helps build up the trust within the founding team necessary to engage in venture creation. A more specialized nested ecosystem, on the other hand, will have fewer potential meeting points for potential entrepreneurs in the two sectors. This means that while entrepreneurs with a finance background may see opportunities, they may struggle to find technology founders who can develop a technological solution and vice versa. This does not prevent innovative entrepreneurship, as founders may still be able to tap into resources and knowledge 
of other industries while still retaining an outsider's perspective that allows them to see new, radical solutions, but it does create barriers to firm formation and entrepreneurial innovation.

However, it is important to note that cohesiveness or nestedness of ecosystems are not determined by the nature of the ecosystem or the industry. Rather, they reflect the individual choices of entrepreneurs which are made within the social constraints of industries, ecosystems, and other social environments. For example, homophily in founding team is driven by the tendency of similar people from similar backgrounds to connect and build the interpersonal trust required to start a new firm together (Reuf et al., 2003). Even in an ecosystem with dense networks that could connect a founder with a diverse array of other potential co-founders with diverse backgrounds (e.g., a programmer meeting a bond trader), that individual's preference to either work with similar or different people will ultimately decide if the founding team has a broad or deep knowledge base.

This means that if FinTech ecosystems tend to be cohesive, this means that the structures of the FinTech industry privilege ventures that bring together insights from both the fields of technology and finance in order to identify emergent opportunities and create new customer value. The ecosystem supports high-growth entrepreneurship by helping founders to build the networks and connections to allow them to build the trust required to share insights and start new firms together. If FinTech firms proliferate in nested ecosystems - meaning founders tend to come from the same industry backgrounds this suggests that the FinTech sector privileges deep industry or technical knowledge, with the ecosystem serving to help entrepreneurs access resources and connects they did not initially possess.

\section{Methods and data}

To better understand the nature of cohesive and nested entrepreneurial ecosystems, this paper examines the backgrounds of founders, senior managers, and advisors at FinTech scale-up firms in four British ecosystems. By examining the professional backgrounds of founders and managers at these firms, we can explore if and how entrepreneurs combine insights from within and outside of their ecosystems to identify new opportunities and develop new product and services. If founders and top managers tend to come from a single type of background (e.g., they are all financial professionals or programmers), this would suggest that they are operating in nested ecosystems that make it hard for founders to find people of other backgrounds that they trust enough to engage in business with. If founding and top management teams have a variety of overlapping backgrounds, this indicates a more cohesive ecosystem that is rich in linkages between different communities.

A major challenge in studying the background of founding and management teams is the lack of individual-level data on their skills, work histories, and education. Such issues have led to calls for researchers to draw on more varied sources of data, such as corporate databases and social media data (Feldman \& Lowe, 2015). To address this challenge, the paper employs two such data sources. First, it uses data from Beauhurst Business Intelligence to identify high-growth FinTech firms along with their founders and senior management teams. Beauhurst identifies high-growth firms based on their product offerings, levels of investment, and use of scale-up programs such as accelerator programs or public R\&D support grants. After identifying firms, Beauhurst gathers data on the founders and top management team, including their gender and job titles, and links to their social media pages if they exist. In mid-2017, data was collected on the 1,315 FinTech firms in the UK which Beauhurst classified as FinTech. Most FinTech firms are clustered in London: 769 (58\%) are located within the Greater London Region compared to 546 (42\%) in the rest of the country. This paper looks at the two largest FinTech ecosystems in London - The City of London and East London (made up of the Hackney and Islington council areas) - as well as the two largest FinTech ecosystems outside of London, Edinburgh, and Leeds.

As shown in Table 1, the City of London and East London are both home to more than one hundred FinTech scale-up firms each, with relatively fewer in Edinburgh and Leeds. After removing firms from the analysis if they were misclassified as FinTech (e.g., they were a traditional investment firm rather than having a technology product) or which were founded before 2005 and therefore could not be considered new ventures, 380 firms were included in the final 
Table 1 Top 10 British ecosystem by FinTech scale-ups (study regions italicized)

\begin{tabular}{ll}
\hline Ecosystem & $\begin{array}{l}\text { Count of } \\
\text { FinTech } \\
\text { scale-ups }\end{array}$ \\
\hline City of London & 193 \\
Westminster & 140 \\
East London (Tech City) & 137 \\
Camden & 84 \\
Tower Hamlets & 61 \\
Southwark & 36 \\
Lambeth & 25 \\
Edinburgh & 31 \\
Leeds & 19 \\
Cardiff & 16 \\
\hline
\end{tabular}

Source: Beauhurst Business Intelligence

dataset: 193 firms in the City of London, 137 in East London, 31 in Edinburgh, and 19 in Leeds.

The City of London has long been the center of financial services in the United Kingdom, including the London Stock Exchange, the Bank of England, and the headquarters of major firms such as Lloyds Banking Group and Aviv (Cook et al., 2007). It is one of the world's largest financial clusters and it has seen the development of a large cluster of FinTech firms looking to sell new technologies to the globally leading banks and investment firms located there. East London - sometimes referred to as Tech City or Silicon Roundabout - is a technology and software cluster, with concentrations of technical talent, scale-up support programs, and venture capital firms (Nathan, 2020). The ecosystem is known as being center of creative, design-based technology work, with a great deal of socializing between firms and high levels of worker mobility. Though these regions are proximate to each other in London, they can be thought of as having separate ecosystems. The City of London has a unique, inward-facing culture focused on the finance industry while East London has developed a very separate culture around technology innovation and entrepreneurship. Consequently, the two ecosystems have developed their own support programs and networks based around their different orientations.

Edinburgh is the UK's second-largest finance center outside of London, hosting the headquarters of major banks and breakage houses. It is also a successful technology entrepreneurial ecosystem, with a dense network of scale-up support programs and high-growth entrepreneurs. However, there are still significant weaknesses in terms of coordination between government and non-government actors and a fragmented investment community (Miao \& Maclennan, 2019). Finally, Leeds is one of the fastest-growing British economies outside of London and has become a center for back-office services for the global financial industry, with regional headquarters for major British and European banks (Gonzalez \& Oosterlynck, 2014). This includes both major multinational banks and the secondary office of the Bank of England.

The second source of data was the LinkedIn profiles of the founders, top management team, and advisors of these FinTech firms. LinkedIn is a professional social networking site in which users list their personal and professional experience to both connect with others and as a tool for job hunting. This means that users have an incentive to keep their details about their job histories, employers, and educational attainment accurate and up to date. LinkedIn is increasingly used by researchers as a data source because it provides individual-level data on knowledge workers and professionals that is otherwise not available through more traditional sources (Jiang et al., 2017; Spigel \& Vinodrai, 2020).

The LinkedIn profiles of up to seven founders and top managers, as identified by Beauhurst, for all FinTech firms in the four study ecosystems were collected in late 2017. Of these, 524 (33.3\%) were classified as founders, with the remaining $1046(66.6 \%)$ being senior managers or advisors. The data collected included self-written descriptions, their current employers, and job titles those for their previous six jobs, up to two of their listed higher education degrees, and up to six self-reported skills. Not every individual provided all the data, but most users had profiles that contained usable information.

These data were used to create two classifications of each individual in order to provide a robust way of understanding each person's experience and knowledge base: their job background and sector of their prior employers. First, the background classification refers to the skills and expertise they have developed in their jobs and through their education. Individuals' backgrounds were classified into one of six categories based on their current and previous job titles, job descriptions, educational history, and self-description. These backgrounds were finance background (e.g., investment manager, risk analyst, or equity researcher), technology background (e.g., developer 
Table 2 Job background classification of founders and senior managers backgrounds
Source: Author's calculations

\begin{tabular}{|c|c|c|c|c|}
\hline \multirow[t]{2}{*}{ Job background classification } & \multicolumn{2}{|c|}{ Total population } & \multicolumn{2}{|c|}{ Founders only } \\
\hline & Count & $\%$ of total & Count & $\%$ of total \\
\hline Finance background & 353 & $22.5 \%$ & 108 & $20.6 \%$ \\
\hline Technology background & 256 & $16.3 \%$ & 96 & $18.3 \%$ \\
\hline Management background & 687 & $43.8 \%$ & 229 & $43.7 \%$ \\
\hline Other background & 80 & $5.1 \%$ & 32 & $6.1 \%$ \\
\hline Mixed background & 61 & $3.8 \%$ & 27 & $5.0 \%$ \\
\hline Unknown/unclassifiable background & 133 & $8.4 \%$ & 33 & $6.1 \%$ \\
\hline Total & 1570 & $100 \%$ & 524 & $100 \%$ \\
\hline
\end{tabular}

and software engineer), management background (e.g., marketing or sales director), other background (anything else, often a creative or legal background), mixed background (an even mixture of two of these backgrounds), or unknown/unclassifiable (not enough data in their profile or their profile was not available).

To perform this classification, a guide was first developed based on a pilot analysis of the data, which was then applied to the full dataset by two $\mathrm{PhD}$ students acting as coders, who worked independently and were blinded to individuals' names and genders to avoid potential bias. They agreed on $69.7 \%$ of all profiles (Cronbach's $\alpha=0.78$ ), representing overall acceptable levels of inter-rater reliability. It is important to note that backgrounds are based on job titles and self-described skills rather than who their employers were: a human resources professional at an investment bank would be classified as having a management background rather than a financial one. The overall classification distribution is shown in Table 2.

However, job backgrounds and skills are not the only determinant of entrepreneurs' ability to observe opportunities and understand the FinTech market. The nature of their prior employers can create the potential to observe new problems or developments that can be used as a basis for new entrepreneurial ventures. To cover this possibility, a second classification scheme was developed to classify individuals based on the sectors of their prior employers. Data on the last six listed employers on each individual profile was gathered from those employers' LinkedIn pages. In total 4,073 different employers in the dataset. Of these, data were gathered on the 2,460 (60.4\%) firms which had company LinkedIn pages. These pages have a combination of data provided by the firm and imputed by LinkedIn and include information such as a text description of the firm, number of employees with LinkedIn profiles, and founding date. Data on firms could not be acquired if they were too small to have a LinkedIn page or if the individual put in a nonfirm name such as "travelling" or "volunteering" to demarcate gaps in their job histories.

A coding guide was developed based on a pilot analysis of these data and two different research assistants were trained to classify these firms as technology, finance, or other based on each company's LinkedIn description. These descriptions are written by company staff to describe the firm's main activities, history, and mission. Technology firms were those who made and sold a technology-based product. Generally, this included firms that would be considered "FinTech" because their primary product was technological. Finance firms were those who provided a financial service such as brokerage, investment, real estate sales, or securities analysis. Firms not falling into these categories were classified as other. As before, the coders worked independently and were blinded to individual names and genders. They agreed on $70.4 \%$ of classifications (Cronbach's $\alpha=0.77$ ), representing acceptable levels of inter-rater reliability.

Because not enough individuals included their length of employment at each employer, it is not

Table 3 Prior employer classification by founder status

\begin{tabular}{llllll}
\hline $\begin{array}{l}\text { Prior employer } \\
\text { classification }\end{array}$ & \multicolumn{2}{l}{ Total population } & & \multicolumn{2}{c}{ Founders only } \\
\cline { 2 - 3 } & Count & $\%$ & & Count & $\%$ \\
\hline Finance & 419 & $26.7 \%$ & & 130 & $24.8 \%$ \\
Technology & 530 & $33.7 \%$ & & 198 & $37.8 \%$ \\
Other & 270 & $17.2 \%$ & & 100 & $19.1 \%$ \\
Missing & 351 & $22.4 \%$ & & 96 & $18.3 \%$ \\
Total & 1570 & $100 \%$ & & 524 & $100 \%$ \\
\hline
\end{tabular}

Source: Author's calculations 
Table 4 Founder job background by ecosystem

Unknown/unclassified founders removed

$X^{2}=25.9, p<=.05$

\begin{tabular}{llllll}
\hline & \multicolumn{4}{l}{ Count of founders (percentage of ecosystem total) } & \\
\cline { 2 - 6 } & City of London & East London & Edinburgh & Leeds & Total \\
\hline Finance background & $65(28 \%)$ & $33(15.9 \%)$ & $6(14.6 \%)$ & $4(33.3 \%)$ & $108(22.0 \%)$ \\
Technology background & $39(17.0 \%)$ & $49(23.6 \%)$ & $7(17.0 \%)$ & $1(8.3 \%)$ & $96(19.5 \%)$ \\
Management background & $106(46.1 \%)$ & $96(46.2 \%)$ & $24(58.5 \%)$ & $3(25.0 \%)$ & $229(46.6 \%)$ \\
Other background & $11(4.8 \%)$ & $15(7.2 \%)$ & $3(7.2 \%)$ & $3(25.0 \%)$ & $32(6.5 \%)$ \\
Mixed background & $9(3.9 \%)$ & $15(7.2 \%)$ & $1(2.4 \%)$ & $1(8.3 \%)$ & $26(5.3 \%)$ \\
Total & $230(100 \%)$ & $208(100 \%)$ & $41(100 \%)$ & $12(100 \%)$ & $491(100 \%)$ \\
\hline
\end{tabular}

possible to rigorously classify the impact of each employer on their industry knowledge base. Individuals were therefore classified based on the number of prior employers they had in different sectors (see Table 3). For example, if out of seven total jobs listed in the database, 3 were in finance, 2 were technology, and one was other, they would be classified as having a finance employer background. In 33 cases, there were an equal number of finance and other employers and in 56 cases, there were an equal number of technology and other employers. Because the focus is on exposure to finance and technology sectors, these cases with equal distributions were assigned as finance and technology, respectively. In 351 cases (22.4\% of dataset), classification was not possible because either profile information on the individual was not available or they did not have any classifiable employers in their job history.

For both classification schemes, conflicts between assistants were resolved by the author, who examined the individual profiles in questions and compared the data to the coding guideline to make a final classification decision. In many cases, disagreements were caused by the challenges of classifying people with complex work histories, such as people who started their career at technology firms or in technology roles or roles but moved into more managerial roles as their careers progressed. While this method does create the potential for mis-categorization, it is designed to reduce the impact of individual biases and create a robust method for assigning people into different career groups based on unstructured, messy data.

\section{Findings}

As shown in Tables 4 and 5, there are significant differences between the four ecosystems when it comes to the backgrounds of founders and top management teams. East London has the highest proportion of senior managers and founders with technology backgrounds. Interestingly, the City of London does not have the highest rate of founders with finance backgrounds, with Leeds exceeding it. However, when looking at the broader top management team (which includes founders), the City of London has the highest rate of people with finance backgrounds.

But while the raw numbers of founders and senior managers job backgrounds across the four ecosystems are important, the overlap of different founder experience bases within companies is the best way to understand the structure of entrepreneurial ecosystems. As shown in Fig. 1, there is substantial variation in the configurations of job backgrounds between ecosystems. ${ }^{1}$ Overall, of the 188 firms with more than one listed founder, just $23(7.1 \%)$ had at least one founder whose background was in technology and one whose background was in finance. East London had the highest concentration of these overlapping finance and technology founding teams $(9.0 \%)$ while Edinburgh had the lowest with $3.7 \%$. In all the ecosystems, the most common background configuration was only management founders (136 firms, $42.1 \%$ of sample), followed by only finance (56 firms, $17.3 \%$ of sample) and then by an overlap of finance and management backgrounds (23, $7.1 \%$ of sample). When examining at the backgrounds of the entire top management and advisory team, we see that both London ecosystems had relatively high rates of teams with

\footnotetext{
${ }^{1}$ All Venn diagrams were generated using the Ghent University Centre for Bioinformatics and System Biology Venn diagram generator, available at: http://bioinformatics.psb.ugent. be/webtools/Venn/.
} 
Table 5 Top management team by ecosystem
Unknown/unclassified founders removed

$X^{2}=93.39, p<=.001$

\begin{tabular}{llllll}
\hline & \multicolumn{5}{l}{ Count of top management team (percentage of ecosystem total) } \\
\cline { 2 - 6 } & City of London & East London & Edinburgh & Leeds & Total \\
\hline Finance background & $238(31.0 \%)$ & $76(15.1 \%)$ & $22(21.0 \%)$ & $17(28.3 \%)$ & $353(24.6 \%)$ \\
Technology background & $125(16.3 \%)$ & $110(21.8 \%)$ & $16(15.2 \%)$ & $5(8.3 \%)$ & $256(17.8 \%)$ \\
Management background & $353(46.0 \%)$ & $235(50.2 \%)$ & $58(55.2 \%)$ & $23(38.3 \%)$ & $687(47.8 \%)$ \\
Other background & $22(2.9 \%)$ & $39(7.7 \%)$ & $5(4.8 \%)$ & $14(23.3 \%)$ & $80(5.6 \%)$ \\
Mixed background & $30(3.9 \%)$ & $26(5.2 \%)$ & $4(3.8 \%)$ & $1(1.7 \%)$ & $61(4.2 \%)$ \\
Total & $768(100 \%)$ & $504(100 \%)$ & $105(100 \%)$ & $60(100 \%)$ & 1437 \\
\hline
\end{tabular}

backgrounds encompassing both finance and technology (see Fig. 2). There are a smaller number of such firms in Edinburgh and Leeds.

Similar patterns are apparent when looking at individuals' prior employer backgrounds. As shown in Fig. 3, about $10.6 \%$ of all firms in the dataset had at least one founder classified as technology and at least one with a founder classified as finance. There was a diverse array of configurations between the four ecosystems, with Edinburgh having the highest rate of this crossover $(15.4 \%)$ while Leeds had no firms whose founding team combined finance and technology backgrounds.

The employer backgrounds of the top management team showed a general increase in the overlap between people with experience in both the finance and technology industries (see Fig. 4). Nearly 30\% of all firms has this overlap, but Leeds still showed
City of London (6.3\% Fin and Tech)

All firms (7.1\% Fin and Tech)

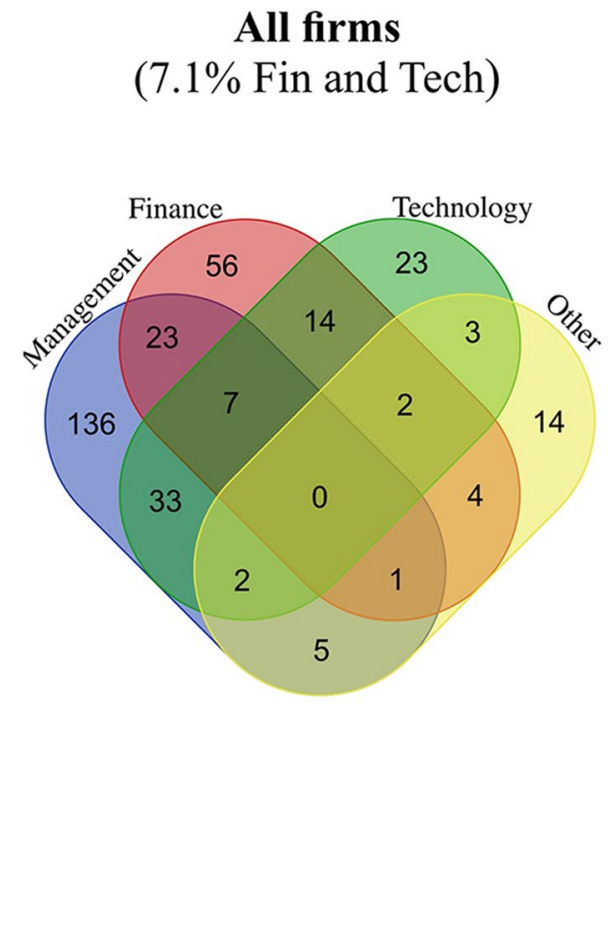

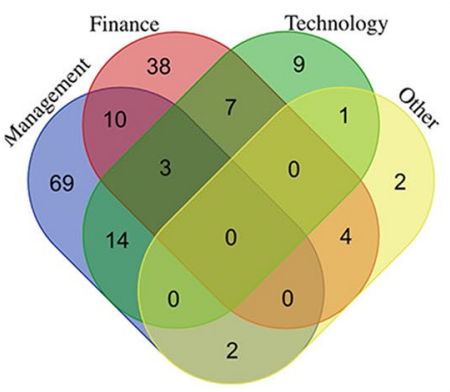

Edinburgh (3.7\% Fin and Tech)

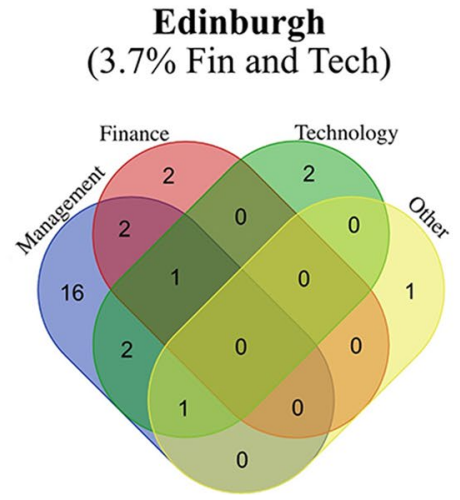

East London $(9.0 \%$ Fin and Tech)

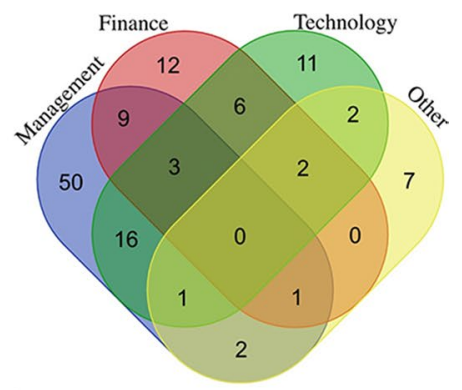

Leeds (6.7\% Fin and Tech)

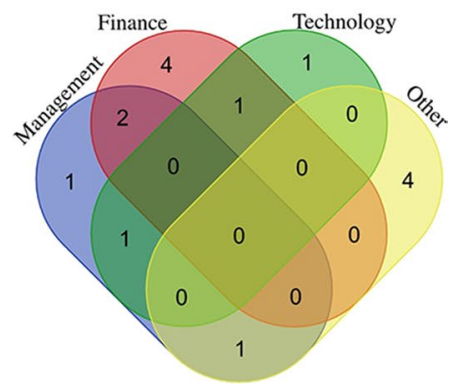

Fig. 1 Configurations of founder job backgrounds. Note: Mixed and missing backgrounds removed for purposes of visualization 
City of London

(26.2\% Fin and Tech)

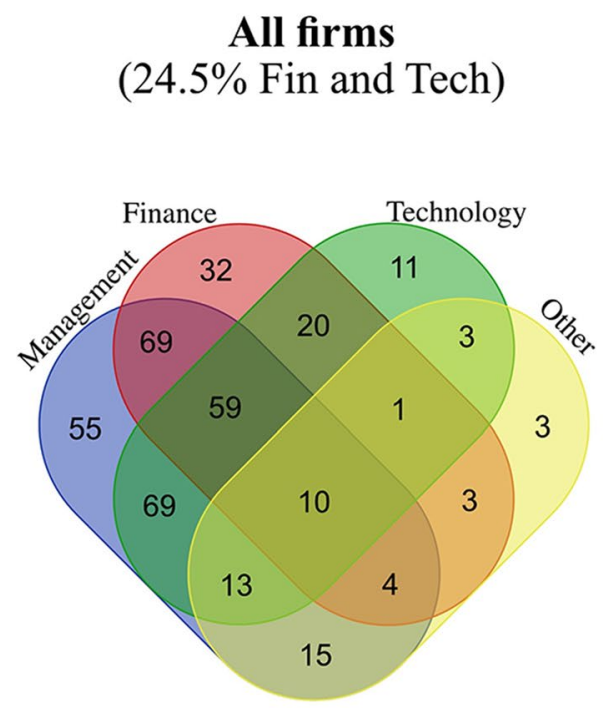

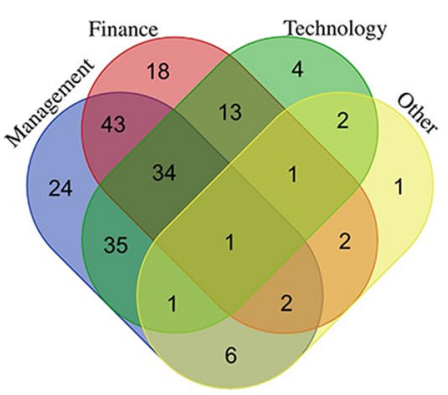

Edinburgh

$(16.6 \%$ Fin and Tech)

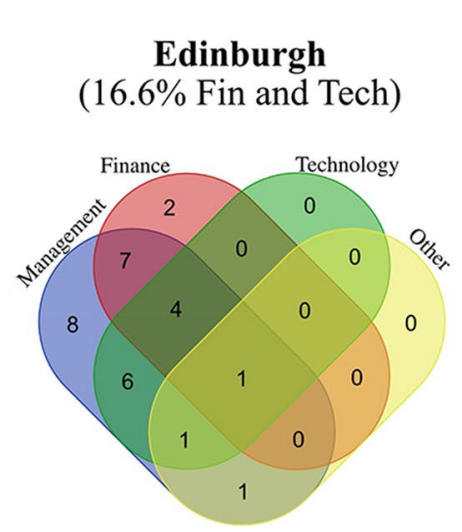

East London

(25.2\% Fin and Tech)

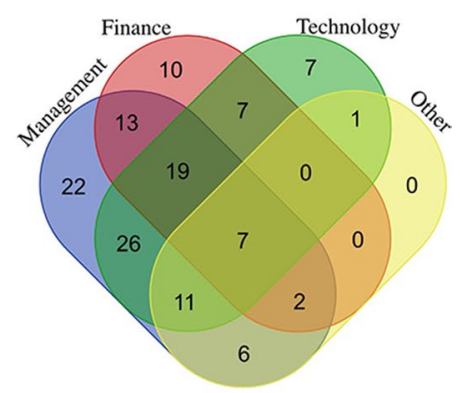

\section{Leeds}

$(15.8 \%$ Fin and Tech)

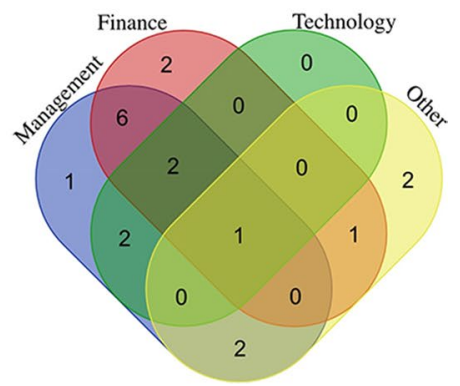

Fig. 2 Configurations of top management team job backgrounds. Note: Mixed and missing backgrounds removed for purposes of visualization

substantially lower levels of overlap in terms of top management teams' backgrounds, with only $18.8 \%$ of firms exhibiting this characteristic, almost $10 \%$ less than the other three ecosystems.

\section{Discussion}

The goal of the paper is to determine if entrepreneurial ecosystems tend to be cohesive, in which entrepreneurial actors draw on a mixture of resources from a wide variety of different sectors, or nested in which entrepreneurs operate within close-knit communities centered around particular sectors or technological vertices. Largely cohesive ecosystems would indicate that ecosystems support entrepreneurial growth by allowing firms to access a broad knowledge base that allows founders to overcome common growth challenges such as access to finance or team building. Nested ecosystems would suggest that ecosystems support growth by helping entrepreneurs access niche technical knowledge and build legitimacy within sectoral niches.

These data indicate that the four ecosystems studied are nested rather than cohesive. The low levels of direct overlap between founders and top managers with finance and technology backgrounds suggest that these two communities are separate, with few opportunities for overlap. While the degree of nestedness differs - for example, there is only one firm in Leeds who has founders from more than one background - mono-background is the modal configuration for FinTech founders in all four locations. This homogeneity is lowered when looking at the broader top management team, but we still observe relatively small levels overlaps of these management teams of those who have experience in technology and finance. To be sure, the London-based ecosystems had higher rates of this overlap than Edinburgh or Leeds, but even then, this accounts for only a quarter of firms. 
City of London

(8.1\% Fin and Tech)

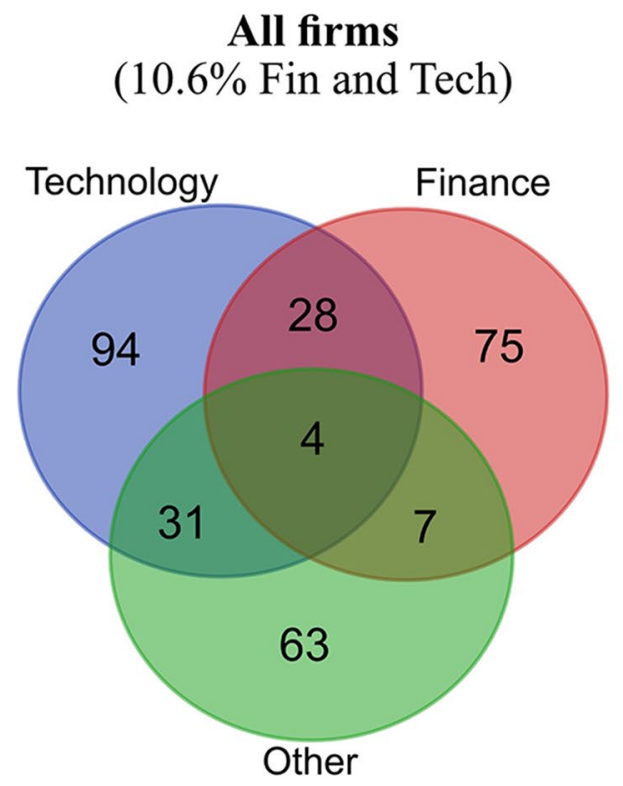

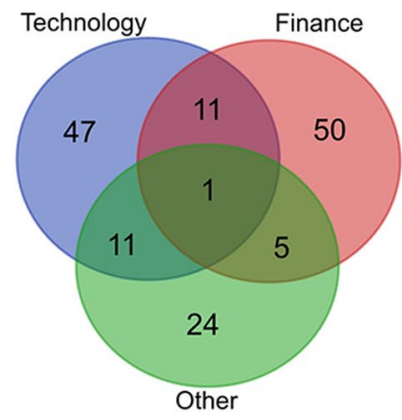

Edinburgh
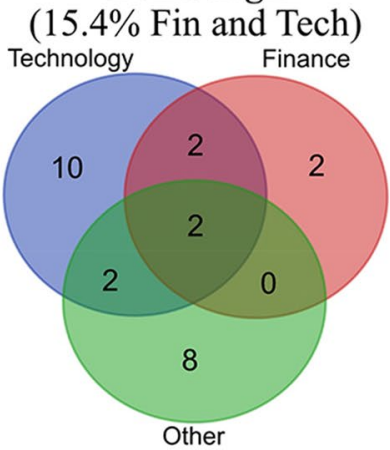

East London

(13.4\% Fin and Tech)

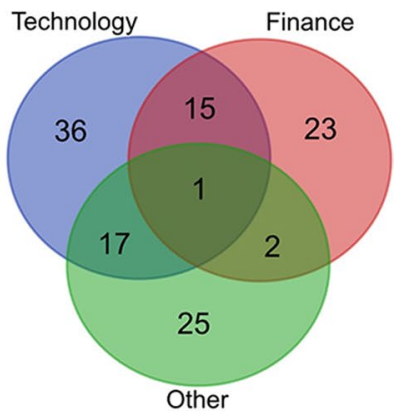

Leeds

$(0 \%$ Fin and Tech $)$

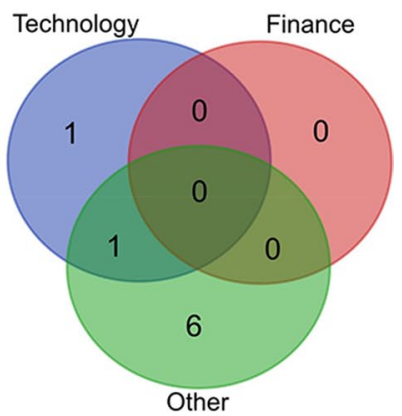

Fig. 3 Founder prior employer background configurations. Note: Missing backgrounds removed for purposes of visualization

These data suggest that highly developed ecosystems provide an opportunity for FinTech entrepreneurs to observe opportunities and then bring on people with technology and finance expertise on to their top management team, helping to address deficiencies in the founders' experience. Even if founding teams infrequently involve people from different backgrounds, these teams were able to increase the types of skills and knowledge bases they can draw on by bringing on outside advisors and managers with different backgrounds. Such hires are facilitated by the ecosystem, which helps founders build out their networks to find and screen qualified workers. However, this was not the case in the less developed ecosystem of Leeds, where background overlap of management teams was substantially lower than in the other three ecosystems. Thus, even if the more developed and more well-functioning ecosystems of London and Edinburgh do not result in more heterogeneous founding teams, these founders are still able to use their local ecosystems to find advisors and managers with different skill sets to help develop new products and grow the firm.

The most unexpected finding is the low number of firms whose founding teams have an overlap of experience between finance and technology. In terms of their career history and employer background, only $7.4 \%$ and $10.7 \%$ of the firms had this founding team configuration, respectively. By either measure, this is a small minority. Even by the broadest measure (prior employer backgrounds of the top management teams), less than a quarter of all firms in the dataset had an overlap between finance and technology. In all ecosystems except Leeds, the modal configuration that the founding teams experience is exclusively in the management domain. These low levels of overlap are a consequence of the number of solo founders. One hundred sixty-three firms, or $46.4 \%$ of the dataset, had only one founder. These numbers are relatively in 
City of London

(28.7\% Fin and Tech)

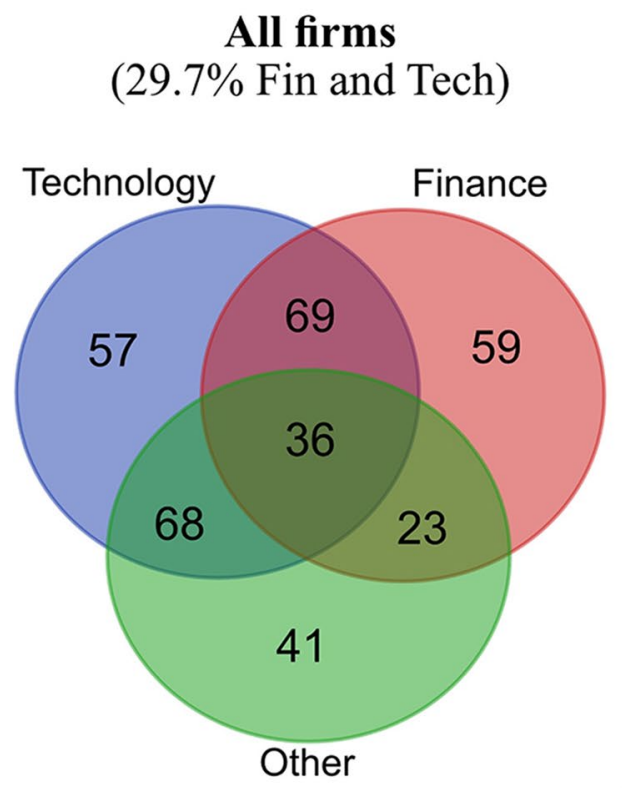

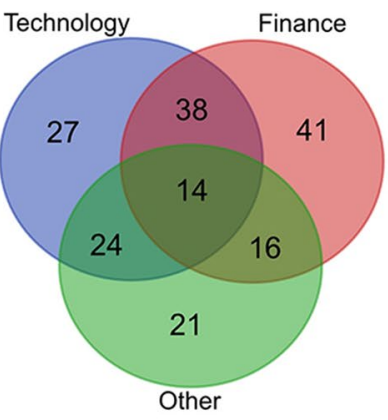

Edinburgh

(27.5\% Fin and Tech)

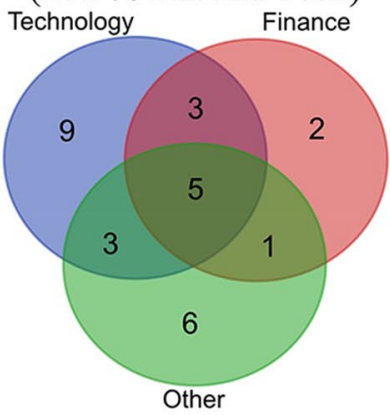

East London

(33.1\% Fin and Tech)

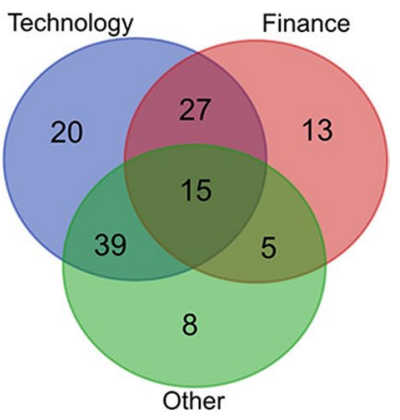

Leeds

(18.8\% Fin and Tech)

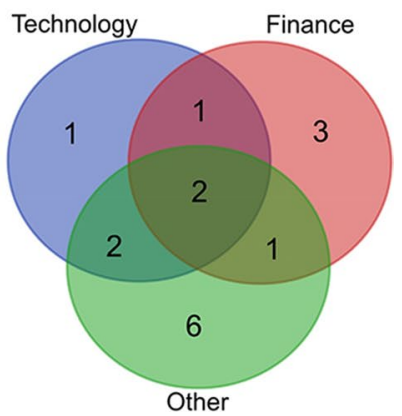

Fig. 4 Top management team prior employer background configurations. Note: Missing backgrounds removed for purposes of visualization

line with other studies of founding teams, where single-founder firms are the plurality (Reuf et al., 2003). But even when expanding the analysis to include top managers and advisors who joined the firm after its founding, we see that there is still a minority of firms whose top management teams have both finance and technology backgrounds. Only $24.5 \%$ (90) of firms had a senior management team with work experience in both sectors and $29.7 \%$ (105) had founders, managers, and advisors whose collective prior employers experience covered both sectors. The most common background of both founding teams and of senior management teams is management. $64.1 \%$ of firms (207) have at least one founder whose background was classified as management. This increases to $80.0 \%$ (294) firms when looking at senior management teams.

The frequency with the founding and top management teams had individuals with a management background speaks to the importance of more generalized business knowledge in the creation and growth of innovative firms. Forty-three firms in the dataset $(11.3 \%)$ had an overlap of founders with managerial and technology backgrounds and 8.4\% of firms (32) had a combination of founders with management and finance backgrounds. One hundred fifty-two firms (40.0\%) had a combination of managerial and technology experience in their top management teams and $37.6 \%$ of firms (143) had a combination of management and finance experience. This suggests that business knowledge is just as important in the FinTech entrepreneurship process as more specialized technological or industry experience. That is, digital affordances mean that FinTech firms use similar tools and techniques as firms outside this sector in order to find opportunities, innovate, and grow. The ecosystem allows FinTech founders with deep, specialized knowledge 
to connect with more generalist managers that can help the company find product-market fit and scale, while simultaneously founders with generalist managerial experience can connect with more specialized finance and technology founders and advisors to help them develop products and penetrate the finance market.

These findings add new dimensions to debates about the role of broad and deep knowledge in firm growth or specialized versus diverse clusters in regional economic development. While there are few direct connections between the technology and finance communities of the four studied ecosystems, founders with specific technical or financial industry experience often partnered with other founders or found top managers who have more managerial backgrounds. The more developed ecosystems in London and Edinburgh appeared to be effective at connecting founding teams with more managers with more general business skills such as operations, marketing, and fund raising, skills that the original founders did not have. This points to the importance of the generic entrepreneurial skills of a top management team in addition to their deep sectoralspecific knowledge that has been previously studied in work on top management teams (Amason et al., 2006; Kor, 2003; Zimmerman, 2008). These generic entrepreneurial skills relate to the ability to evaluate an opportunity and how new technologies enable novel solutions to market gaps but just as importantly the ability to bring together employees and advisors with more specialized knowledge bases to effectively pursue an opportunity. Such managerial skills have received far less attention in the entrepreneurship literature on human capital than technical knowledge, which is easier to proxy through educational background. However, some recent papers such as Siepel et al. (2021) have begun to examine the relationship between diverse founder skills and firm performance. This work tends to show the importance of overlapping skills across a breadth of technical, creative, managerial domains within a firm rather than deep specialization. This organizational structure is supported by diverse ecosystems which contain populations with a variety of talents that can be easily accessed through dense local networks which are built through frequent interactions at formal events and informal meetups.

\section{Conclusion}

These findings make three contributions to the entrepreneurial ecosystems literature. First, it uses a novel dataset and methodology to examine the structure of entrepreneurial ecosystems. The method goes inside the firm to look at the backgrounds of founders and top manager to examine the extent to which ecosystem structure can bring together people of different backgrounds and experiences to identify opportunities in the FinTech space. By responding to Feldman and Lowe's (2015) call for more creative use of different types of data, this paper developed a new perspective on the development paths of entrepreneurial ecosystem. LinkedIn offers a rich way to systematically identify not just key players in an ecosystem but also the types of skills, backgrounds, and insights available. Combining LinkedIn data with other public sources such as Meetup.com (A. Rocha et al., 2021) and Twitter (Hannigan et al., 2021) can provide policymakers with a much clearer understanding of the resources within ecosystems as well as the gaps. Researchers should proactively engage with this and other novel datasets to understand the ofteninvisible dynamics and resources of entrepreneurial ecosystems.

Second, it finds that ecosystems are substantially nested, even in highly developed ones in central London. Nested ecosystems imply that there are multiple distinctive communities within their own dense internal connections instead of a single cohesive community of entrepreneurial actors. This finding helps address important questions in the entrepreneurial ecosystems literature and highlights the importance of more generic forms of scale-up know-how as opposed to specialized technological or market insight.

Third, the paper finds that even though the ecosystems have nested communities of technology and finance entrepreneurs, the importance of managerial founders and top management teams speaks to the importance of more generic forms of entrepreneurial knowledge in the scale-up process. Indeed, the sheer preponderance of founders, advisors, and top managers with backgrounds in management also suggests that nested FinTech ecosystems are not just specialized finance or technology clusters. Rather, it speaks to the importance of generic entrepreneurial and business know-how in the venture 
development and scaling process alongside more specialized technological knowledge or industryspecific networks and legitimacy. The ecosystem enables non-specialized founders to quickly identify experienced experts who can join the firm as advisors or senior workers.

When interpreting these conclusions, it is important to note the weaknesses of the method and data. There is substantial missing data about founders and managers and since we do not have information on how long they were in different job roles, some individuals may be misclassified. It is also possible for people to gain the knowledge needed to see an important FinTech opportunity outside their normal job: a programmer might have an active interest in the crypto-currency market that gives her new insights into an important user need. The study is also limited to the British FinTech sector: it is difficult to say if the findings are generalizable to other sectors or national contexts. FinTech is unique both due to its openness on the consumer product side but also due to the highly regulated nature of more complex offerings. Other industries without these characteristics may be more amenable to highly cohesive ecosystems. Other very specific industries like aerospace or biotech might only have nested ecosystems with few connections to those without very deep experience in that niche. Further work is required to see if the overall cohesiveness of the ecosystems in this study is a general trend or if this is a unique consequence of the nature of FinTech or British entrepreneurship.

These findings are also useful to ecosystem builders and policymakers. The data used in this paper shows that sources like LinkedIn can be used The findings are also useful for policymakers in thinking through what actions are more important for improving the quality of the ecosystem. It is clear that the less developed ecosystem of Leeds had less background diversity of its FinTech founding and top management teams. Ensuring that founders can develop their own entrepreneurial and business skills and access senior managers with the business skills that they lack is a crucial aspect of the ecosystem that may need direct support when existing networks within the community are not yet dense enough. These findings also suggest that success in one sector within an ecosystem will not necessarily contribute to the development of other sectors in a large ecosystem.
Building on this work, future research can continue to draw on new, novel data from social media and other sources that allow for more detailed examinations of not just what firms are in entrepreneurial ecosystems, but who is starting and running these firms and what their knowledge bases encompass. This allows for new perspectives not possible with traditional datasets. Ideally, further work would look specifically at the networks between founders and their top managers and advisors to understand how these links were forged in order to study the connections between different communities within a broader ecosystem. This could then reveal, for instance, if different aspects of the ecosystem help or hamper links between groups. More broadly, this work calls for a closer look at the relationships between entrepreneurs and other actors in ecosystems to better understand how these connections developed, if by random happenstance or mediated through other actors in the ecosystem. The goal is to understand the complexity of how these relationships are formed and maintained and how they lead to the recombination of knowledge and know-how that produce innovative entrepreneurship. To what extend does the ecosystem support the development of radical knowledge spillovers between different groups within a community or foster the creation of trust-based bonds between potential cofounders and senior employees. This could provide new evidence for the core processes through which regional entrepreneurial ecosystems contribute to venture innovation and growth.

Acknowledgements I am thankful for the hard work of the project's coders: Fizza Khalid, Siliang Yang, Florian Koehne, and Marta Bernal Valencia. I am also grateful for the supportive comments of the editor and anonymous reviewers.

Funding This paper was funded by a Frank H. Kenan Institute of Private Enterprise Frontiers of Entrepreneurship Research Grant.

Frank H. Kenan Institute of Private Enterprise Frontiers of Entrepreneurship Research Grant

Open Access This article is licensed under a Creative Commons Attribution 4.0 International License, which permits use, sharing, adaptation, distribution and reproduction in any medium or format, as long as you give appropriate credit to the original author(s) and the source, provide a link to the Creative Commons licence, and indicate if changes were made. The images or other third party material in this article are included in the article's Creative Commons licence, unless indicated otherwise in a credit line to the material. If material is not 
included in the article's Creative Commons licence and your intended use is not permitted by statutory regulation or exceeds the permitted use, you will need to obtain permission directly from the copyright holder. To view a copy of this licence, visit http://creativecommons.org/licenses/by/4.0/.

\section{References}

Acs, Z. J., \& Armington, C. (2004). The impact of geographic differences in human capital on service firm formation rates. Journal of Urban Economics, 56(2), 244-278. https://doi.org/10.1016/j.jue.2004.03.008

Amason, A. C., Shrader, R. C., \& Tompson, G. H. (2006). Newness and novelty: Relating top management team composition to new venture performance. Journal of Business Venturing, 21(1), 125-148. https://doi.org/10.1016/j. jbusvent.2005.04.008

Arner, D. W., Barberis, J., \& Buckley, R. P. (2016). The evolution of FinTech: A new post-crisis paradigm? Georgetown Journal of International Law, 47, 1271-1318.

Asheim, B. T., \& Gertler, M. S. (2006). The geography of innovation: Regional innovation systems. Oxford University Press. https://doi.org/10.1093/oxfordhb/9780199286 805.003.0011

Audretsch, D. B., \& Belitski, M. (2016). Entrepreneurial ecosystems in cities: Establishing the framework conditions. The Journal of Technology Transfer, 42(5), 1030-1051.

Auerswald, P. E., \& Dani, L. (2017). The adaptive life cycle of entrepreneurial ecosystems: The biotechnology cluster. Small Business Economics, 49(1), 97-117.

Autio, E., Nambisan, S., Thomas, L. D. W., \& Wright, M. (2018). Digital affordances, spatial affordances, and the genesis of entrepreneurial ecosystems. Strategic Entrepreneurship Journal, 12(1), 72-95.

Barringer, B. R., Jones, F. F., \& Neubaum, D. O. (2005). A quantitative content analysis of the characteristics of rapid-growth firms and their founders. Journal of Business Venturing, 20(5), 663-687. https://doi.org/10.1016/j. jbusvent.2004.03.004

Bathelt, H., \& Zhao, J. (2016). Conceptualizing multiple clusters in mega-city regions: The case of the biomedical industry in Beijing. Geoforum, 75(C), 186-198. https:// doi.org/10.1016/j.geoforum.2016.07.016

Baumol, W. (1990). Entrepreneurship: Productive, unproductive, and destructive. Journal of Political Economy, 98(5 Part 1), 893-921.

Beugelsdijk, S., \& Noorderhaven, N. (2004). Entrepreneurial attitude and economic growth: A cross-section of 54 regions. Annals of Regional Science, 38, 119-218.

Brown, R., \& Mason, C. (2017). Looking inside the spiky bits: A critical review and conceptualisation of entrepreneurial ecosystems. Small Business Economics, 49(1), 11-30.

Brown, R., \& Mawson, S. (2019). Entrepreneurial ecosystems and public policy in action: A critique of the latest industrial policy blockbuster. Cambridge Journal of Regions, Economy and Society, 12(3), 347-368. https://doi.org/10. 1093/cjres/rsz011
Cantner, U., Cunningham, J. A., Lehmann, E. E., \& Menter, M. (2020). Entrepreneurial ecosystems: A dynamic lifecycle model. Small Business Economics. https://doi.org/10. 1007/s11187-020-00316-0

Cao, Z., \& Shi, X. (2020). A systematic literature review of entrepreneurial ecosystems in advanced and emerging economies. Small Business Economics. https://doi.org/10. 1007/s11187-020-00326-y

Chen, J., Cai, L., Bruton, G. D., \& Sheng, N. (2019). Entrepreneurial ecosystems: What we know and where we move as we build an understanding of China. Entrepreneurship \& Regional Development, 62(5-6), 370-388. https://doi.org/ 10.1080/08985626.2019.1640438

Cohen, S. L., Bingham, C. B., \& Hallen, B. L. (2018). The role of accelerator designs in mitigating bounded rationality in new ventures. Administrative Science Quarterly, 15(4), 810-854-45. https://doi.org/10.1177/0001839218782131

Contigiani, A., \& Levinthal, D. A. (2019). Situating the construct of lean start-up: Adjacent conversations and possible future directions. Industrial and Corporate Change, 28(3), 551-564. https://doi.org/10.1093/icc/dtz013

Cook, G., Pandit, N., Beverstock, J., Taylor, P., \& Pain, K. (2007). The role of location in knowledge creation and diffusion: Evidence of centripetal and centrifugal forces in the City of London financial services agglomeration. Environment and Planning A, 39, 1325-1345.

Doloreux, D., \& Turkina, E. (2021). New path creation in the artificial intelligence industry: Regional preconditions, new actors and their collective actions, and policies. Regional Studies, 1-13. https://doi.org/10.1080/00343 404.2021.1919610

Ewens, M., Nanda, R., \& Rhodes-Kropf, M. (2018). Cost of experimentation and the evolution of venture capital. Journal of Financial Economics, 128(3), 422-442. https:// doi.org/10.1016/j.jfineco.2018.03.001

Feldman, M., \& Lowe, N. (2015). Triangulating regional economies: Realizing the promise of digital data. Research Policy, 44(9), 1785-1793.

Feldman, M. P. (2014). The character of innovative places: Entrepreneurial strategy, economic development, and prosperity. Small Business Economics, 43(1), 9-20. https://doi.org/10.1007/s11187-014-9574-4

Felin, T., \& Hesterly, W. S. (2007). The knowledge-based view, nested heterogeneity, and new value creation: Philosophical considerations on the locus of knowledge. Academy of Management Review, 32(1), 195-218. https://doi.org/10. 5465/amr.2007.23464020

Fritsch, M., \& Kublina, S. (2018). Related variety, unrelated variety and regional growth: The role of absorptive capacity and entrepreneurship. Regional Studies, 52(10), 13601371. https://doi.org/10.1080/00343404.2017.1388914

Gonzalez, S., \& Oosterlynck, S. (2014). Crisis and resilience in a finance-led city: Effects of the global financial crisis in Leeds. Urban Studies, 51(15), 3164-3179. https://doi.org/ 10.1177/0042098013519142

Hannigan, T. R., Briggs, A. R., Valadao, R., Seidel, M.-D. L., \& Jennings, P. D. (2021). A new tool for policymakers: Mapping cultural possibilities in an emerging AI entrepreneurial ecosystem. Research Policy, 104315. https://doi. org/10.1016/j.respol.2021.104315 
Harris, J. L. (2021). Bridging the gap between 'Fin' and 'Tech': The role of accelerator networks in emerging FinTech entrepreneurial ecosystems. Geoforum, S0016718521001093. https://doi.org/10.1016/j.geoforum. 2021.04.010

Hasan, S., \& Koning, R. (2019). Prior ties and the limits of peer effects on startup team performance. Strategic Management Journal, 40(9), 1394-1416. https://doi.org/10. 1002/smj.3032

Henry, N., Angus, T., \& Jenkins, M. (2021). Motorsport Valley revisited: Cluster evolution, strategic cluster coupling and resilience. European Urban and Regional Studies, 096977642110160. https://doi.org/10.1177/0969776421 1016039

Ho, K. (2009). Liquidated: An ethnography of Wall Street. Duke University Press

Horváth, K., \& Rabetino, R. (2019). Knowledge-intensive territorial servitization: Regional driving forces and the role of the entrepreneurial ecosystem. Regional Studies, 53(3), 330-340. https://doi.org/10.1080/00343404.2018.14697 41

Isenberg, D. J. (2010). The big idea: How to start an entrepreneurial revolution. Harvard Business Review, 88, 40-50.

Jiang, J. X., Wang, I. Y., \& Wang, K. P. (2017). Revolving rating analysts and ratings of MBS and ABS: Evidence from LinkedIn. Management Science, 64(2), 5832-5854.

Kenney, M., \& Patton, D. (2005). Entrepreneurial geographies: Support networks in three high-technology industries. Economic Geography, 81(2), 201-228.

Ketelhöhn, N. W. (2006). The role of clusters as sources of dynamic externalities in the US semiconductor industry. Journal of Economic Geography, 6(5), 679-699. https:// doi.org/10.1093/jeg/lb1007

Klepper, S. (2007). Disagreements, spinoffs, and the evolution of Detroit as the capital of the U.S. automobile industry. Management Science, 53(4), 616-631. https://doi.org/10. 1287/mnsc. 1060.0683

Kor, Y. Y. (2003). Experience-based top management team competence and sustained growth. Organization Science, 14(6), 707-719. https://doi.org/10.1287/orsc.14.6.707. 24867

Lafuente, E., Vaillant, Y., \& Vendrell-Herrero, F. (2017). Territorial servitization: Exploring the virtuous circle connecting knowledge-intensive services and new manufacturing businesses. International Journal of Production Economics, 192, 19-28. https://doi.org/10.1016/j.ijpe.2016.12.006

Lee, S. S., \& Osteryoung, J. (2004). A comparison of critical success factors for effective operations of university business incubators in the United State and Korea. Journal of Small Business Management, 42(4), 418-426.

Mack, E., \& Mayer, H. (2016). The evolutionary dynamics of entrepreneurial ecosystems. Urban Studies, 53(10), 2118-2133.

Maleki, A., \& Rosiello, A. (2019). Does knowledge base complexity affect spatial patterns of innovation? An empirical analysis in the upstream petroleum industry. Technological Forecasting and Social Change, 143, 273-288. https:// doi.org/10.1016/j.techfore.2019.01.020

Massa, L., Tucci, C. L., \& Afuah, A. (2017). A critical assessment of business model research. Academy of
Management Annals, 11(1), 73-104. https://doi.org/10. 5465/annals.2014.0072

Miao, J. T., \& Maclennan, D. (2019). The rhetoric-reality gap of cities' success: Learning from the practice of Scottish cities. Regional Studies, 53(12), 1761-1771. https://doi. org/10.1080/00343404.2019.1597970

Motoyama, Y., \& Knowlton, K. (2016). From resource munificence to ecosystem integration: The case of government sponsorship in St Louis. Entrepreneurship \& Regional Development, 28(5-6), 448-470.

Nakatsu, R. T., \& Iacovou, C. L. (2009). A comparative study of important risk factors involved in offshore and domestic outsourcing of software development projects: A twopanel Delphi study. Information \& Management, 46(1), 57-68. https://doi.org/10.1016/j.im.2008.11.005

Nathan, M. (2020). Does light touch cluster policy work? Evaluating the tech city programme. Research Policy, 104138. https://doi.org/10.1016/j.respol.2020.104138

Nathan, M., \& Rosso, A. (2015). Mapping digital businesses with big data: Some early findings from the UK. Research Policy, 44(9), 1714-1733.

Neumeyer, X., \& Corbett, A. C. (2017). Entrepreneurial ecosystems: Weak metaphor or genuine concept? In Advances in the study of entrepreneurship, innovation, and economic growth (pp. 35-45). Emerald Publishing Limited. https://doi.org/10.1108/S1048-473620170000027005

Nylund, P. A., \& Cohen, B. (2017). Collision density: Driving growth in urban entrepreneurial ecosystems. International Entrepreneurship and Management Journal, 13(3), 757776. https://doi.org/10.1007/s11365-016-0424-5

Philippon, T. (2016). The FinTech opportunity. National Bureau of Economic Research. https://doi.org/10.3386/ w22476

Pittz, T. G., White, R., \& Zoller, T. (2019). Entrepreneurial ecosystems and social network centrality: The power of regional dealmakers. Small Business Economics, 56, 1273-1286. https://doi.org/10.1007/s11187-019-00228-8

Porter, M. (1998). Clusters and the new economics of competition (pp. 77-90). November-December: Harvard Business Review.

Qian, H., Acs, Z. J., \& Stough, R. R. (2013). Regional systems of entrepreneurship: The nexus of human capital, knowledge and new firm formation. 13, 559-587.

Reuf, M., Aldrich, H., \& Carter, N. M. (2003). The structure of founding teams: Strong ties and isolation among U.S. entrepreneurs. American Sociological Review, 68(2), 195-222.

Rocha, A., Brown, R., \& Mawson, S. (2021). Capturing conversations in entrepreneurial ecosystems. Research Policy, 50(9), 104317. https://doi.org/10.1016/j.respol.2021. 104317

Rocha, H. O., \& Sternberg, R. (2005). Entrepreneurship: The role of clusters theoretical perspectives and emperical evidence from Germany. Small Business Economics, 24(3), 267-292. https://doi.org/10.1007/s11187-005-1993-9

Schildt, H., Keil, T., \& Maula, M. (2012). The temporal effects of relative and firm-level absorptive capacity on interorganizational learning. Strategic Management Journal, 33(10), 1154-1173. https://doi.org/10.1002/smj.1963

Siepel, J., Camerani, R., \& Masucci, M. (2021). Skills combinations and firm performance. Small Business 
Economics, 56(4), 1425-1447. https://doi.org/10.1007/ s11187-019-00249-3

Spigel, B. (2017). The relational organization of entrepreneurial ecosystems. Entrepreneurship Theory and Practice, 41(1), 49-72.

Spigel, B. (2020). Entrepreneurial ecosystems: Theory, practice and futures. Edward Elgar Publishing

Spigel, B., \& Harrison, R. T. (2018). Towards a process theory of entrepreneurial ecosystems. Strategic Entrepreneurship Journal, 12(1), 151-168.

Spigel, B., \& Vinodrai, T. (2020). Meeting its waterloo? Recycling in entrepreneurial ecosystems after anchor firm collapse. Entrepreneurship \& Regional Development

Stam, E. (2015). Entrepreneurial ecosystems and regional policy: A sympathetic critique. European Planning Studies, 23(9), 1759-1769.

Stam, E., \& van de Ven, A. (2021). Entrepreneurial ecosystem elements. Small Business Economics, 56(2), 809-832. https://doi.org/10.1007/s11187-019-00270-6

van Weele, M. A., Steinz, H. J., \& van Rijnsoever, F. J. (2017). Start-up communities as communities of practice: Shining a light on geographical scale and membership. Tijdschrift Voor Economische En Sociale Geografie, 109(2), 173-188. https://doi.org/10.1111/tesg.12277
Wurth, B., Stam, E., \& Spigel, B. (2021). Toward an entrepreneurial ecosystem research program. Entrepreneurship Theory and Practice, 1042258721998948. https://doi.org/ $10.1177 / 1042258721998948$

Zhou, K. Z., \& Li, C. B. (2012). How knowledge affects radical innovation: Knowledge base, market knowledge acquisition, and internal knowledge sharing. Strategic Management Journal, 33(9), 1090-1102. https://doi.org/10.1002/ smj.1959

Zimmerman, M. A. (2008). The influence of top management team heterogeneity on the capital raised through an initial public offering. Entrepreneurship Theory and Practice, 32(3), 391-414. https://doi.org/10.1111/j.1540-6520. 2008.00233.x

Publisher's note Springer Nature remains neutral with regard to jurisdictional claims in published maps and institutional affiliations. 